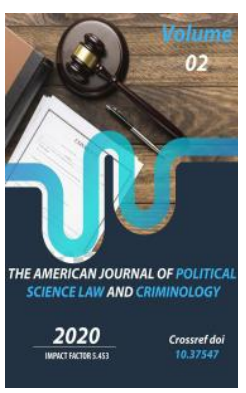

\title{
Some Ideas On The Regulation Of Migration Processes
}

\author{
Behzod Egamberdiyev
}

Teacher Of The Academy Of The Ministry Of Internal Affairs Of The Republic Of Uzbekistan

Copyright: Original content from this work may be used under the terms of the creative commons attributes 4.0 licence.

\section{ABSTRACT}

This article analyses theoretical bases of the migration process on the basis of national and foreigner scientists' contemplative thoughts, moreover, author's proposals and recommendations on the improvement of theoretical sides of migration are expounded. In particular, the article analyzes the statistics of regulation of migration processes and the views of scientists on such concepts as migration, illegal migration, migration process, internal and external migration. The author emphasizes that the concept of migration is interconnected with the concepts of "illegal migration", "migration management", "mechanisms of migration regulation" and "activities related to migration processes" based on scientific, theoretical and legal norms.

The article also discusses the views of scientists on migration in order to improve the scientific and theoretical basis for regulating migration processes. The final part of the article gives the author's definition of the concepts of "migration", "illegal migration", "migration process" and "migration control", which serve to strengthen the theoretical and legal foundations of migration.

\section{KEYWORDS}

Migration, illegal migration, process of migration, refuge-seeker, refugee, regular migration, internal and external migration, voluntarily eviction, forcibly eviction, organizational migration, labor migration, migration of crime. 


\section{INTRODUCTION}

According to the UNO documents, the process of migration is indispensable part of socialeconomic development of the countries, as a means of reducing inequality in the world community in boot[1]. In some areas, the situation is aggravated by the migration of the population [2].

"... Armed conflicts in South-East Asia and the Middle East, mutual disbelief and conflicts are intensifying, deepening inter-ethnic and interconfessional conflicts, and other global threats and challenges menace to sustainable development [3]. Participation of the drop-out persons, refugees and other migrants as the source of these threats is very topical.

According to migration data, the number of international migrants has risen to $\$ 173$ million in 2000. In 2010, the total number of migrants has risen to 220 million and up to 272 million by 2019. These facts confirm that migrant dynamics are growing in the international arena [4]. In the development of these trends, the sustainability of the contribution of international migrants of the world in 2050, will rise dramatically by $48,8 \%$ or to 405 million people. According to the regional analysis of these processes, $61.2 \%$ of migrants will live in Asia (80 million) and Europe (78 million), 22.4\% in North America (58 million), 9.6\% in Africa (25 million) and $3,8 \%$ in Latin America and the Caribbean (10 million) in forthcoming years [5]. Also, in some publications, every year approximately $2-3 \%$ of the world's population changes their place of residence [6].

From this point of view, the issues of regulation of migration are foremost in protection of migrants rights and freedoms, interests of the individual, national security of the state and society, and socio-economic stability and demographic development of the country, moreover, the analyses of scientific and theoretical aspects of migration and regulation have organizational and legal significance.

\section{RESULTS AND ITS DISCUSSION}

Migration is a historical and social phenomenon; its initial definition is scientifically grounded by the English scientist E.G. Rubenstein (1885-1889). According to him, "migration" is the process of permanent or temporary change of a person's place of residence. Its narrowed meaning is that people change the place of residence, and widened meaning is explained by the eviction or relocation of a person.

In the glossary of the International Organization for Migration (IOM), the term "migration" is described as "the process of movement of the population in the international borders or within the area of the country, regardless of their duration, content, or origin" [7].

Hence, migration processes primarily involve the voluntary movement of the population to other regions, and, secondly, the actions related to their forcibly eviction or relocation. However, the growth of the migration process is characterized by the fact that the war as a complex social phenomenon is a major social and economic change in some countries and threatens the stability and security of neighboring states and regions. Security issues related to migration processes can be seen in the research by scientists such as D. Humans, K. Krause, M. Williams, K. But and R. Jones [8]. The focus of these researches is on the aspects related to the social essence of migration and the context of national security [9].

Besides that, in some publications, the term of migration has been described as a factor that 
changes the demographic structure of the migrated and immigrated population in the administrative regions, and in others, it's described as the arrival, departure, transit, and transformation of the population. In this regard, it is possible to see that there are various scientific-theoretical interpretations of the concept of "migration" according to the views of scientists and experts.

In particular, Russian scientists T.I.Zaslavska, G.S.Vechkanov and A.Axezer[10] differently interpreted the concept of "population migration". In particular, T.Zaslavska outlines that "the population's migrations" is the practice of changing people's dwelling and move from place to place. G.S.Vechkanov believes that, migration is along with the free movement of people, is to change the place of work and place of residence together with individual, collective and social interests[10]. A.S.Ahiezer described the population migrations as "a certain element of the changing lifestyle or type of activity that describes the population's forcibly eviction or change of living and workplaces temporarily or permanently"[10]. In this regard, the social needs of the population in the migration processes are taken into account; however the legal aspects of migration processes are not addressed.

This aspect of the migration process is described by Professor M.Kh.Rustamboev. He defined this term as "breaking the border of the state by crossing the checkpoints or territorial boundaries, regardless of the type of transportation by (air, water, vehicle, etc.)[11].

Nevertheless, in the special literature on migration regulation, the concept of migration means the demographic features of any territorial location, which unites migrants regardless of their location or functioning in one or more administrative-territorial units
[12]. This definition describes "how migration is a major factor in the migration process" as Yu.V.Roshchin clarified, furthermore he glossed that "migration is a process that changes people's demographic position of the human lifestyle in geographic location for permanent or temporary movement from one society to another"[13].

However, this definition has not been regarded as ideal by scientists owing to disconnection of this term to the purpose of migration and the purpose of leaving the migratory residence altogether.

In this context, based on the views of scientists on migration, in our viewpoint, the concept of "migration" means the process of permanent or temporary change or change of place of residence with the social and legal attitudes for various reasons as a result of one or more actions of citizens, foreigners and stateless persons.

From the point of view of migration management, the concept of "migration process" is mainly understood through administrative-legal and social relations as one of the components of legal regulation and place of residence as a series of international migration affairs [14].

The migration process can be described as a set of regional or abroad movements of the place of residence (work) of a person relating to departure, entry, and transit. In some publications, the "migration process" is explained by the concept of population movement. In our opinion, the "migration process" is not just a formality of population movement, but a unity of legal movement of population with migration.

In this regard, Academician V.A.Borisov chose two main directions of population movement in migration process [15]. In his opinion, the 
movement of the population includes changes in the dynamics of birth and death, the level of marriage and divorce, as well as changes in the number of people as a result of the transformation of a person into age and sex. Thus, the mechanical movement of the population can be understood as a territorial action. However, this conclusion does not reflect a number of reasons that lead to population mobility.

In the special literature, the concept of "migration process" is classified as different as the term "migration", and the migration process is grounded thoroughly that the regulation of this process should be on the bases of international legal standards and national legislation, focusing on the significance of the law [16]. In this regard, I.Yu.Fozilov argued that national legislation defines the responsibility for organizing illegal migration, which provides for the legal regulation of migration processes (Criminal Code, article 2231)[17].

The main goal is to prevent early migrationrelated crime, such as human trafficking, terrorism, extremism and drug trafficking through the regulation of migration processes. Because, in some criminological sides of migration-related research studies, the term "migratory crime" refers to the perception of migrants (immigrants or locals) in the territory of recipient countries or transnational migrants as well as migrants in the territory of recipient or transit states too [18].

In this regard, A.N.Torenko tried to substantiate the process of regulating migration-regulation not only with legal relations, but also through social approaches. In other words, he scientifically grounded the particular features of regulation of migration processes by dividing the emigration factors in three directions: a) migration policy, b) integration policy, and c) differentiating the concept of "migration management" and "regulation of migration" [19].

According to G.A.Chekhoev, the essence of regulation of migration processes in the country's development is based on the socioeconomic, demographic development of the country and the human, the security of the society and the state, the economic needs of the labor force, the distribution of the country's administrative territories and the intellectual and labor potential use in the migration process [20].

In our opinion, this process can not be evaluated merely by economic factors, but should be considered as a matter of ensuring the constitutional rights of migrant workers and regulating the migration process. Therefore, the Law of the Republic of Uzbekistan "On ratification of the Constitution of the International Organization for Migration (Brussels, October 19, 1953)" was adopted.

This is a long-term "Concept of Migration Policy in Uzbekistan", which defines the priority areas of effective migration processes in Uzbekistan, protecting the rights and freedoms of migrants, promoting the interests of the individual, society and the state, identifying the priorities of national security and sustainable socio-economic and demographic development of the country, moreover, the necessity to adopt a law "On Migration" in the Republic of Uzbekistan.

Taking into consideration all the facts and surveys on scientific and theoretical bases of migratory process, in our research we made up our mind to differentiate the migration process into several criteria, according to the norms of diversity of the nature of the migration process, geographical features, continuation, the reasons for occurrence (optional, 
compulsory), organizational-administration, and the juridical importance.

During the course of this investigation, we depicted that the practitioner-staffs have some difficulties in understanding the skills of learning the methods, forms and types of the regulation of the migration process in lawenforcement activity of the organs of internal affairs.

Hencefore, in our opinion, it is desirable to provide the author's definition of the following concepts, which envisages the improvement of the theoretical basis of migration law and regulation in the law enforcement practice of the organs of internal affairs:

$\checkmark$ Migration - is a process of permanent or temporary change or change of place of residence with the social and legal attitudes for various reasons as a result of one or more actions of citizens, foreigners and stateless persons.

$\checkmark$ Migration process - is a set of regional or abroad movements of the place of residence (work) of a person relating to departure, entry, and transit.

$\checkmark$ Labor migration - the process of labor relations connected with the temporary change of a person's place of residence for work in abroad;

$\checkmark$ Migration control - a set of measures aimed at preventing, identifying and eliminating violations of the legislation governing migration processes;

$\checkmark \quad$ Illegal migration - a set of organizational and legal actions aimed at the implementation of the rules of entrance, departure and stay of a person in his or her home territory and transit them through violation of law.

\section{REFERENCES}

1. United Nations Food and Agriculture Organization (FAO) report on October 15th, 2018. https://www.google.com/amp/s/ria.ru/ amp/world/20181015 /1530676068. html.(date of apply: November 2nd , 2018.)

2. Candidate for the President of the Republic of Uzbekistan Shavkat Mirziyoyev`s report in VIII plenary session of "The action of businessmen and entrepreneurs" - Uzbekistan liberal-democratic party: "Consistent continuation of democratic reforms, creation of peace and calm, worthwhile living conditions for our people - is the guarantee of constant development. // Xalk suzi. - 2016. November 2nd.

3. Mirziyoyev Sh. Universal Declaration of Human Rights 70 years ends: modern threads and reality // Report in Asian forum on human rights, Samarkand. 2018. Nov.22nd // Xalk suzi. - 2018. November 23.

4. United Nations Department of Economic and Social Affairs // https://www.un.org/development/des a/en/news/population/internationalmigrant $2019 \mathrm{html}$.

5. United Nations, Department of Economic and Social Affairs, Population Division (2017). International Migration Report 2017: Highlights (ST/ESA/ SER. A/404).

6. Glushchenko G.I., Ponomarev V.A. Migration and development. - $M$.: Economy, 2009.

7. Glossary on migration // International Organization for Migration (IOM). 2004. Geneva. Internet: http://www.iom.int. 
8. Jef Huymans. The Politics of Insccurity, Fear? Migration and Asylum in the EU, London, Routledge, 2006; Jef Huymans, "Defing Social Constructivism in Security Studies: The Normative Dilemma of Writing Security", Alternatives, Special Issue, Vol. 27, 2002. p. 41-62.

9. National security system. Co-authors. State governing Academy under the President of the Republic of Uzbekistan. Handbook. -T.: Academy, 2014. - Pp. 190-200.

10. Tyurkin M.L. Migration system of Russia. Monograph.-M: Publishing house "Strategy". 2005., Volokh V.A. Labor migration: political, legal and socio-economic aspects of attracting and using foreign labor. Monograph. // M .: Publishing House "Sputnik", 2010., Akhiezer A.S. "Polity" / Migration in Russian history. 2004. No. 4.

11. Rustamboev M.Kh. Explanations of the Criminal Code of the Republic of Uzbekistan. [Reviewed and completed second edition until November 1st, 2016] special part / Rustamboev M.Kh.

- Tashkent: “Адолат”, 2016. - Рр. 610612.

12. Rybakovsky L.L. Population migration (theoretical questions). Chapter 1. - M .: ISPI RAN, 2003.

13. Roshchin Yu.V. Population migration and Russia. (The role and significance of migration processes in migration policy in the past, present and future of the Russian state): textbook.-M.: GUU, 2007.

14. Solovieva E.A., Ivanchenko D.Yu. The concept and essence of the migration process // [Electronic resource] URL: pglu.ru supload / iblock / 12a / 10.pdf

15. Borisov V.A. Demography - $M$.: NOTABENE, 2001.
16. Solovieva E.A., Ivanchenko D.Yu. The concept and essence of the migration process 2012.// [Electronic resource] URL: pglu.ru supload / iblock / 12a / 10.pdf.

17. Fozilov I.Yu. Criminal-legal and criminologic features of the fight against human trafficking: author. dis. ... jurid. sciences. T., 2016.-106 p.

18. Nasurov P.A. Criminal consequences of illegal migration and measures to prevent them: auto. dis. ... Cand. jurid. sciences. M., 2008.17 p.

19. Torenko A.N. Organizational mechanism for regulating migration processes in the border region (based on materials from the Far Eastern Federal District): author. dis. ... Cand. jurid. sciences. M., 2015.15 p.

20. Chekhoev G.A. Institute of citizenship in the system of constitutional and legal regulation of migration relations: author. dis. ... cond. Law. sciences. M., 2007.23 p. 